\title{
Kecemasan pada perempuan yang menghadapi menopause; Sebuah tinjauan literatur
}

\author{
Yuni Wulan Sari $^{1 *}$, Eva Yunitasari ${ }^{2}$, Riska Hediya Putri ${ }^{3}$ \\ ${ }^{1,2,3,}$ Universitas Aisyah Pringsewu \\ Email: yuni06sari@gmail.com
}

\begin{tabular}{l} 
ARTICLE INFO \\
\hline Keyword: \\
Anxiety \\
Menopause \\
Kecemasan \\
*) corresponding author \\
Mahasiswa Program Studi Profesi Ners \\
Fakultas Kesehatan Universitas Aisyah \\
Pringsewu \\
J1. A. Yani No. 1A Tambahrejo Kecamatan \\
Gadingrejo Kabupaten Pringsewu Lampung \\
35372 Telp: (0729) 333343
\end{tabular}

\begin{abstract}
A B STRACT
One of the stages of life that is definitely experienced by every woman is menopause. Menopause is not having menstruation for 12 consecutive months due to ovaries that have progressively failed in producing the hormone estrogen, follicles in the ovary experience decreased activity that can cause menstruation to stop so that women do not menstruate forever (WHO, 2016). Changes that often occur during menopause are physical changes, ranging from hair, eyes, skin to other physical organs. Target physical organs such as problems in the breast and vagina, as well as hot flashes that arise in the body (Hot Flashes). Not only physical changes that occur at menopause, psychological changes also occur at this time. The problems that arise from these psychological changes cause anxiety in most women. This type of research is research using the literature study method or literature review. Analysis using analysis of journal contents. The results of this study the factors that affect anxiety at menopause are physical changes, education, age, knowledge, family support, economic status, number of children, age of menarche, behavioral, cognitive and affective responses. For handling anxiety in menopause can be given hormonal replacement therapy to reduce symptoms and anxiety in menopause, guidance and counseling services. Suggestion: To health workers in Puskesmas or hospitals to provide counseling or guidance and counseling services. So that all mothers can know what menopause is and do activities that can benefit society to reduce the number of women who experience anxiety in dealing with physical, psychological, and sexual changes in menopause.
\end{abstract}

This is an open access article under the CC-BY-SA license.

\section{PENDAHULUAN}

Salah satu tahap kehidupan yang pasti dialami oleh setiap wanita adalah menopause. Menopause adalah tidak mengalami menstruasi selama 12 bulan berturut-turut diakibatkan yang 
diakibatkan ovarium secara progresif telah gagal dalam memproduksi hormon estrogen, folikel dalam ovarium mengalami penurunan aktivitas yang dapat menyebabkan menstruasi berhenti sehingga wanita tidak mengalami menstruasi selamanya (WHO, 2016).

Berdasarkan jumlah penduduk dan derajat kesehatan masyarakat Indonesia pada tahun 2020 diperkirakan jumlah wanita yang hidup dalam usia menopause adalah 30,3 juta orang. Dengan semakin meningkatnya wanita menopause maka akan meningkat pula jumlah wanita pasca menopause. Perubahan yang banyak terjadi pada saat menopause ialah perubahan fisik, mulai dari rambut, mata, kulit sampai keorgan-organ fisik lainnya.Target organ fisik seperti masalah di payudara dan vagina, serta muncul rasa panas yang menjalar di tubuh (Hot Flashes). Tidak hanya perubahan fisik yang terjadi pada menopause, perubahan psikis pun muncul pada saat ini. Masalahmasalah yang timbul dari perubahan psikis ini menimbulkan rasa cemas pada kebanyakan wanita. Kecemasan yang menimbulkan rasa cemas pada kebanyakan wanita.

Menurut Yanti, Erlamsyah, Zikra, \& Ardi (2013) kecemasan merupakan keadaan emosional yang tidak menenangkan seperti perasaan tertekan dalam menghadapi kesulitan yang ditandai dengan adanya perasaan khawatir, prihatin dan rasa takut pada situasi tertentu. Kecemasan yang muncul pada wanita menopause sering dihubungkan dengan adanya kekhawatiran dalam menghadapi suatu situasi yang sebelumnya tidak pernah dikhawatirkan (Feldman \& Papalia, 2014).

Umumnya mereka tidak mendapat informasi yang benar sehingga yang dibayangkannya adalah efek negatif yang akan dialami setelah memasuki masa menopause. Mereka cemas dengan berakhirnya era reproduksi yang berarti berhentinya nafsu seksual dan fisik (Feldman \& Papalia, 2014). Kecemasan yang dialami seseorang pada masa menopause dapat diamati melalui tiga aspek yaitu aspek respon perilaku, aspek respon kognitif, dan aspek respon afektif (Stuart, 2014).

Ketika memasuki usia menopause mulai terjadi perubahan dan penurunan kualitas pada fisik, hal tersebut merupakan gejala yang dialami oleh wanita menjelang menopause. Perubahan tersebut dapat menimbulkan perasaan cemas. Kecemasan adalah keadaan khawatir emosional dengan mengeluh bahwa sesuatu yang buruk akan terjadi (Alizamar, Fikri, \& Afdal, 2017).

Dari hasil penelitian yang dilakukan oleh Fitria Edni Wari (2017) diperoleh hasil bahwa kecemasan ibu dalam menghadapi perubahan fisik masa menopause di Desa Sambung Rejo Kecamatan Sukodono Kabupaten Sidoarjo adalah sebagian besar responden terjadi kecemasan sebanyak 36 responden (60,0\%). Selanjutnya penelitian yang dilakukan oleh Kartini Syahmudin, Chatrina M.A Bajak, Gracia membahas tentang Hubungan Kecemasan Pada Menopause namun, belum ada yang membahas secara literature Review dari penelitian-penelitian Ch. Tooy (2018) menunjukkan bahwa hasil penelitian di Kampung Naha 1 Kecamatan Tabukan Utara tentang Tingkat Kecemasan Ibu dalam menghadapi Masa Menopause dengan jumlah 25 responden diperoleh Tingkat Kecemasan yang paling banyak ialah tingkat Kecemasan dengan kategori Panik sebanyak 13 responden (44\%). Kesimpulan dari penelitian ini adalah Tingkat Kecemasan Ibu dalam menghadapi Masa Menopause memilki Tingkat Kecemasan yang Panik. Saat ini ada beberapa penelitian yang yang dibuat. Oleh sebab itu peneliti tertarik untuk melakukan telaah jurnal Kecemasan pada Menopause.

\section{METODE}

Metode yang digunakan dalam penulisan artikel ini adalah tinjauan literature (literature review) terhadap teori-teori yang relevan baik internasional maupun nasional. Sumber literature meliputi studi pencarian yang didapatkan sebanyak 10 artikel hasil penelitian pada jurnal yang relevan. 


\section{HASIL DAN PEMBAHASAN}

Kecemasan merupakan gejolak emosi seseorang yang berhubungan dengan sesuatu diluar dirinya dan mekanisme diri yang digunakan dalam mengatasi permasalahan (Asmadi, 2018). Pada umumnya Kecemasan akan datangnya memasuki usia 50 tahun pada wanita menopause. Menopause merupakan haid terakhir pada wanita yang sering diartikan sebagai berakhirnya fungsi reproduksi seorang wanita. Walaupun menopause merupakan hal yang normal, tidak jarang seorang wanita takut menghadapi datangnya menopause (Jhaquin, 2010)

Berdasarkan jurnal yang didapatkan bahwa dari 10 jurnal faktor-faktor kecemasan menopause yaitu perubahan fisik, pendidikan, umur, pengetahuan, dukungan keluarga, status ekonomi, jumlah anak, usia menarche, respon perilaku, kognitif dan afektif.

Perubahan fisik, psikologis seperti hot fluss (rasa panas) pada wajah, leher, dan dada, berkeringan dimalam hari, berdebar-debar atau detak jantung meningkat atau mengencang, susah tidur, sakit kepala, keingginan buang air kecing lebih sering dan mudah lupa merupakan tanda dan gejala pada menopause yang dapat menyebabkan kecemasan pada menopause

Wanita dengan pengetahuan kurang atau cukup (belum maksimal) mempunyai peluang 3 kali berisiko mengalami kecemasan dalam menghadapi menopause, dibandingkan dengan wanita yang memiliki pengetahuan yang baik (Lusiana, 2014). Pendidikan yang kurang menyebabkan terbatasnya responden dalam memperoleh informasi di bangku sekolah, responden akan cenderung sulit untuk mendapatkan informasi dan menyerap informasi tentang menopause sehingga menimbulkan kecemasan pada masa menopause. Semakin tinggi pendidikan responden semakin baik pula dalam menyerap informasi yang di aplikasikan dalam bentuk tindakan atau penilaian dalam hal ini berhubungan dengan perubahan pada masa menopause.

Usia adalah usia individu yang terhitung mulai saat dilahirkan sampai saat berulang tahun. Semakin cukup umur, tingkat kematangan dan kekuatan sesorang akan lebih matang dalam berfikir dan bekerja. Dari segi kepercayaan masyarakat seseorang yang lebih di percaya dari orang yang belum cukup tinggi kedewasaannya. Hal ini sebagai akibat dari pengalaman dan kematangan jiwanya. Seseorang yang mempunyai usia lebih tua ternyata lebih mudah mengalami gangguan kecemasan dari pada seseorang yang lebih muda, tetapi ada juga yang berpendapat sebaliknya (Stuart, 2017).

Dukungan keluarga adalah bentuk sikap, tindakan penerimaan keluarga terhadap anggota keluargannya, berupa dukungan informasional, dukungan penilaian, dukungan instrumental dan dukungan emosional (Mukhlis, H., Kristianingsih, A., Fitrianti, F., Pribadi, T., Kumalasari, D., Febriyanti, H., \& Maseleno, A. 2020).. Jadi dukungan keluarga adalah suatu bentuk hubungan keluarga mengacu kepada dukungan-dukungan sosial yang dipandang oleh anggota keluarga sebagai sesuatu yang dapat diakses atau diadakan untuk keluarga yang selalu siap memberikan pertolongan dan bantuan jika diperlukan (Utini, 2015).

Menurut Rosenthal (2009), pada masa menopause dukungan sangat dibutuhkan. Banyak wanita mengalami kecemasan pada masa menopause disebabkan oleh karena mereka takut kehilangan rasa sayang dari suami atau keluarga karena sudah tidak menarik lagi dan tidak berguna lagi (Lusiana, 2014).

Semakin sering seorang wanita melahirkan maka semakin tua atau lama wanita tersebut memasuki masa menopause. Hal ini dikarenakan kehamilan dan persalinan akan memperlambat sistem kerja organ reproduksi wanita dan juga dapat memperlambat penuaan tubuh. Manuaba (2005). Wanita menarche 8 tahun akan memasuk usia menopause 55 tahun, usia menarche 13 tahun akan memasuki usia menopause 50 tahun sedangkan usia menarche 19 tahun akan memasuki usia menopause 45 tahun.16 Hal ini sesuai dengan pendapat Setyo yang berpendapat bahwa wanita yang mendapatkan menstruasi pada usia 16 atau 17 tahun akan mengalami menopause lebih dini, 
sedangkan wanita yang haid lebih dini seringkali akan mengalami menopause sampai pada usianya mencapai 50 tahun.

Perilaku yang ditunjukkan oleh wanita ketika menghadapi gejala menopause yang sedang terjadi merupakan bentuk dari ketidaksiapan wanita dalam menjalankan salah satu tugas perkembangan pada masa ini. Wanita merasa cemas terhadap perubahan fisik yang terjadi pada dirinya, sehingga hal tersebut mempengaruhi rasa percaya diri wanita. Kepercayaan diri dipengaruhi oleh gambaran terhadap diri sendiri (Ifdil, Denich, \& Ilyas, 2017). Hal ini berarti apabila gambaran yang dimiliki oleh wanita yang menghadapi menopause positif, maka kepercayaan diri akan meningkat dan mengurangi rasa cemas. Karena salah satu tugas perkembangan yang harus dilalui dengan baik oleh wanita dewasa madya ialah tugas yang berkaitan dengan perubahan fisik (Hurlock, 2012). Tugas ini berkaitan dengan penerimaan dan penyesuaian diri dengan berbagai perubahan fisik yang normal terjadi pada usia madya.

Gejala yang tampak dalam diri individu menjadi cemas, sulit untuk berkonsentrasi, sulit untuk tidur, sulit untuk membuat keputusan dan terlalu terpaku pada bahaya yang tidak jelas asalnya. Haber \& Runyon (1984) menjelaskan bahwa ketika individu mengalami kecemasan, gejala kognitif yang ditimbulkan dapat bervariasi dari khawatir ringan hingga panik. Hal itu dapat mempengaruhi kemampuan berkonsentrasi, mengambil keputusan, dan sulit tidur.

Kecemasan yang dialami ditandai dengan perasaan tegang, perasaan khawatir, dan merasa waspada. Kekhawatiran yang dialami oleh wanita ketika mulai menopause merupakan menifestasi dari kurangnya pemahaman diri maupun pasangan mengenai menopause. Sehingga wanita menjadi kesulitan dalam menjelaskan perubahan yang terjadi kepada suami, dan merasa bahwa perubahan itu akan berdampak buruh terhadap keharmonisan hubungannya dengan suami. Kurangnya dukungan dari suami maupun keluarga dekat dapat membuat wanita menjadi lebih cemas. Kecemasan dimanifestasikan pada perasaan emosi individu seperti adanya bahaya yang mengancam dan menimpa dirinya sehingga individu merasa tidak nyaman dan sangat khawatir dan gelisah yang berlebihan (Rostiana \& Kurniati, 2009).

Hasil penelitian menurut Fitria Edni Wari, (2017) wanita menunjukkan merasa cemas saat melihat diri dalam cermin yang semakin tua, keriput dan tidak cantik lagi anda menjadi takut sendiri. Keadaan fisik seorang wanita menopause mengalami banyak perubahan akibat perubahan organ reproduksi dan juga hormon tubuh dan mengalami kecemasan pada menopause.

Adapun hasil penelitian menurut Meilita Enggune, dkk (2018) menunjukkan bahwa dari penggunaan farmakologi seperti HRT (hormone replacement theraphy) atau terapi sulih hormone dan serotonin dan terapi norepinefrin antidepresan dan terapi fitoestrogen juga sangat efektif, dapat mengurangi gejala dan kecemasan pada menopause seperti hot flushes, berkeringat dimalam hari, mengurangi kecemasan, emosional atau depresi. Hal ini sesuai dengan teori Fox-Spencer \& Brown (2007) penangan menopause adalah dengan menggunakan Terapi Hormonal (Terapi Sulih Hormon/TSH) Terapi hormon yang biasa digunakan pada wanita menopause adalah sulih estrogen, karena gejala menopause disebabkan oleh defisiensi estrogen. Terapi sulih hormon terdapat dalam beberapa jenis sediaan seperti tablet, plester (patch), implan, semprot hidung, cincin vagina, gel, dan krim atau tablet vaginal.

Hasil penelitian menurut Tisa Anggraini, Zikra1, (2019) Berdasarkan hasil penelitian Kecemasan Wanita Dalam Menghadapi Menopause dan Implikasinya Dalam Layanan Bimbingan Dan Konseling menunjukkan bahwa tingkat kecemasan dengan tingkat sedang, faktor kecemasan yaitu respon perilaku, kognitif dan afektif dan untuk mengatasi masalah yang terjadi pada wanita yang merasa cemas menjelang masa menopause dapat dibantu dengan pemberian layanan bimbingan dan konseling.

Layanan bimbingan dan konseling adalah proses pemberian bantuan oleh seorang konselor kepada klien dengan tujuan untuk mengembangkan potensi yang dimiliki klien dan mengentaskan 
masalah yang dialami klien (Prayitno \& Amti, 2004). Salah satu layanan yang dapat diberikan kepada pasangan yang mengalami masalah dalam kehidupan pernikahan yaitu layanan konseling pernikahan dan keluarga (Yendi, Ardi, \& Ifdil, 2013). Selain itu pemberian layanan informasi mengenai menopause dan gejala-gejalanya juga dapat diberikan kepada wanita dewasa madya yang memasuki usia menopause. Penyesuaian diri individu dapat meningkat setelah diberikan layanan informasi yang tepat sasaran terhadap kebutuhannya (Desneli, Firman, \& Sano, 2016)

Dalam literature review pada 10 jurnal ini yang membahasa tentang pada masa menopause sering terjadinya kecemasan di dapat kan hasil bahwa faktor-faktor kecemasan menopause yaitu perubahan fisik, pendidikan, umur, pengetahuan, dukungan keluarga, satatus ekonomi, jumlah anak, usia menarche, respon perilaku, kognitif dan afektif dan untuk penanganan gejala dan kecemasan pada menopause dapat dengan menggunakan terapi sulih hormone, layanan bimbingan dan konseling sehingga dapat mengurangi kecemasan pada menopause.

Berdasarkan penelitian yang dilakukan tentang perbandingan antara terapi sulih hormone dengan pemberian bimbingan serta layanan konseling sama-sama memiliki kemampuan untuk mengurangi atau menghilangkan rasa cemas pada menopause.

\section{KESIMPULAN DAN SARAN}

Menopause di artikan sebagai tidak mengalami menstruasi selama 12 bulan berturut-turut yang diakibatkan ovarium secara progresif telah gagal dalam memproduksi hormon estrogen, folikel dalam ovarium menagalami penurunan aktivitas yang dapat menyebabkan menstruasi berhenti sehingga wanita tidak mengalami menstruasi selamanya. faktor-faktor kecemasan menopause yaitu perubahan fisik, pendidikan, umur, pengetahuan, dukungan keluarga, satatus ekonomi, jumlah anak, usia menarche, respon perilaku, kognitif dan afektif dan untuk penanganan gejala dan kecemasan pada menopause dapat dengan menggunakan terapi sulih hormone, layanan bimbingan dan konseling sehingga dapat mengurangi kecemasan pada menopause.

Pemberian layanan bimbingan, konseling dan terapi sulih hormone agar semua ibu-ibu dapat mengetahui apa itu menopause serta melakukan kegiatan yang dapat bermanfaat terhadap masyarakat untuk menurunkan jumlah wanita yang mengalami kecemasan dalam menghadapi perubahan fisik, psikologis, dan seksual pada menopause.

\section{DAFTAR PUSTAKA}

Anggraini, Tisa dan Zikra. 2019. Women's Anxiety In Facing Menopause And Its Implications In Guidance And Counseling Services. Jurnal Neo Konseling Vol.1 No.2.

Bekti, Safitrianti Dwi dan Laily Mualifah. 2018. The Relationship Of Stress Tolerance With Coping Mechanism Of Pre-Menopause Women. Jurnal Kesehatan Karya Husada Vol.6 No.1.

Enggune, Meilita, dkk. 2018. The Anxiety Of Perimenopause Women In Facing Menopause. Journal Vol. 2 No.1.

Feldman, P., \& Papalia, D. (2014). Menyelami Perkembangan Manusia (Experience Human Development). Jakarta: Salemba Humanika

Fithriyana, Rinda. 2019. Faktor-Faktor Yang Berhubungan Dengan Kecemasan Ibu Menghadapi Menopause Di Desa Suka Damai Wilayah Kerja Puskesmas Ujung Batu Rohul. Jurnal Doppler Vol.3 No.1.

Kopciuch, Dorota. 2017. Conventional or Natural Pharmacotherapy and the Prevalence of Anxiety and Depression During Menopause. Journal Vol. 23 No. 2. 
Mukhlis, H., Kristianingsih, A., Fitrianti, F., Pribadi, T., Kumalasari, D., Febriyanti, H., \& Maseleno, A. (2020). The effect of expressive writing technique to stress level decrease of new student at Al-Falah Putri Islamic Boarding School, Margodadi, Tanggamus. Annals of Tropical Medicine and Health, 23, 192-200.

Rosyada, Mujahidah Amrina. 2016. Faktor - Faktor Yang Berhubungan Dengan Usia Menopause. Jurnal kesehatan masyarakat Vol. 4 No. 1.

Septiani, Minda dan Cut Muslihati. 2019. Faktor-Faktor Yang Memengaruhi Kecemasan Dalam Menghadapi Menopause Di Desa Meunasah Dayah Kecamatan Peusangan Kabupaten Bireuen. Journal of Healthcare Technology Vol. 5 No. 2.

Syahmudin, Kartini. dkk. 2018. Tingkat Kecemasan Ibu Dalam Mengahadapi Masa Menopause Di Kampung Naha 1 Kecamatan Tabukan Utara. Jurnal ilmiah sesebanua Vol.2 No. 1.

Wari, Fitria Edni. 2017. Kecemasan Ibu Dalam Menghadapi Perubahan Fisik Masa Menopause Di Desa Sambung Rejo Kecamatan Sukodono Kabupaten Sidoarjo. Jurnal Vol 9 No. 1.

WHO. 2016. Menopause pada Wanita . Yogjakarta: EGC.

Yanti, S., Erlamsyah, E., Zikra, Z., \& Ardi, Z. (2013). Hubungan antara Kecemasan dalam Belajar dengan Motivasi Belajar Siswa. Konselor, 2(1).

Yuni, Irwan. 2018. Hubungan Citra Tubuh Dengan Kecemasan Pada Wanita yang Mengalami Menopause di Gampong Ateuk Pahlawan Kecamatan Baiturrahman Banda Aceh. Jurnal aceh medika Vol. 2 No. 1. 